\title{
Protein Society Consumption Pattern Of Jambi Province
}

\author{
Adi Putra ${ }^{1}$, Deka Veronica ${ }^{2}$ \\ Faculty of Economics and Business, University of Muhammadiyah Jambi, Indonesia.
}

Protein consumption for the community is very important and must be known, because improving nutritional status is the basis for the formation of quality, healthy, intelligent, productive, and independent human resources in an area. The level of public protein consumption, especially from beef products, is strongly influenced by the conditions of product supply and demand, because these indicators also affect prices and the level of inflation in general. For this reason, research needs to be done specifically to analyze the effect of price, inflation and per capita expenditure on the protein consumption pattern of the people in Jambi Province. The design of this research is a quantitative analysis of time series data for the period 2007-2018 which is further analyzed by Path Analysis. The results showed that there was no direct influence between the variable foodstuff inflation (IBM) and Beef Price (HDS) on Community Per Capita Expenditure (PBM), but PBM had an effect on Community Protein Consumption (KPM). The indirect effect between IBM on KPM through PPM and HDS on KPM through PPM has a significant effect. To maintain a healthy condition for protein consumption in Jambi Province, the government needs to take policies such as maintaining a stable condition of foodstuff inflation and beef prices in the market.

Keywords: Foodstuff Inflation, Beef Prices, Public Protein Consumption.

OPEN ACCESS

ISSN 2528-4649 (online) ISSN 2338-4409 (print)

Reviewedby: Dr. Sri Langgeng Ratnasari, S.E., M.M ${ }^{*}$ Correspondence: Adi Putra putra102005702@gmail.com Received: December 25, 2020 Accepted: February 28, 2021 diterima Published: March 31, 2021 JBMP: Jurnal Bisnis, Manajemen dan Perbankan. Vol: $7 /$ No. 1 doi: 10.21070/jbmp.v7i1.1197 


\section{INTRODUCTION}

Most people's protein consumption comes from animal protein such as beef, because animal protein is useful as a source of energy and can form various enzymes and hormones, as well as support the enhancement of the human immune system. Daily protein needs are important and must be fulfilled properly, just like the need for fat and carbohydrates, protein is also one of the nutrients that the body needs in large quantities. When we consume foods that contain protein, the digestive system will break down protein into amino acids which are needed in almost all parts of the body, especially as a source of energy and elements to build and repair tissue and replace tissue in the body that has been damaged. Proteins can also form antibodies to fight bacterial infections, destroy toxins, and digest food. (Bintang, 2010).

Efforts to fulfill community protein individually are strongly influenced by internal and external factors, Winarni (2000) argues that internal factors affect community protein needs, namely the lack of knowledge and public awareness of the importance of nutrition, as well as the lack of participation of entrepreneurs in fulfilling the nutrition of workers in their company. . Djambak (2011) suggests an external factor that affects the fulfillment of public nutrition, namely the inflation rate in an area, because if the inflation rate is difficult to control, it will directly affect the demand and supply of community protein source products.

Inflation is also very susceptible to external disturbances, if a shock occurs due to an increase in food or energy prices, the national inflation spike without being balanced by an increase in nominal population income will cause the burden of life for the people, especially the lower economic strata, to get heavier. Furthermore, the condition of inflation that continues to increase to an unreasonable number encourages consumers to save on expenses and hold back on purchases of goods or services so that it will damage the economic planning patterns of economic actors (Angriyani 2013).

It is very important to know the effect of foodstuff inflation and the price level of animal protein source products such as beef, because these two variables are variables that directly affect the public financial system, especially in determining investment instruments and public consumption expenditure patterns. Mankiw (2013) states "Consumption is goods or services purchased by consumption households consisting of non-durable goods, which consist of: First, goods that are used up in a short time, such as food and clothing; Second is durable goods (Durable Goods) that have a long life, such as cars, televisions, electronic devices: Third is services (Services) which include work performed for consumers by individuals and companies. Reksoprayitno (2000) explains that people's consumption expenditure is determined by income, to maintain the level of consumption when their income decreases is to reduce the amount of saving, then additional income will cause an increase in expenditure for consumption, while the increase in saving is not so fast.
The researcher who examines the pattern / behavior of public protein consumption in Indonesia is Wahyuni (2016) who specifically analyzes the partial elasticity of the price of protein source foods and the area where households live on the share of expenditure on consumption of protein source foods, then Umaroha (2018) which is specific analyze the consumption of animal protein which is shown specifically in the aspect of availability of ingredients such as beef, chicken, fish and milk in Indonesian households.

The difference between this study and the two studies mentioned above is that this study more specifically analyzes the pattern of public protein consumption from the characteristics of the influence of foodstuff inflation, beef commodity prices and per capita income of the community with criteria that are more specifically adjusted to the socioeconomic conditions of the community in Jambi Province.

Some of the hypotheses to be formulated in this study are in the form of direct and indirect effects between the following variables:

H1 = Food inflation has a direct effect on the foodstuff expenditure of the people of Jambi Province.

$\mathrm{H} 2=$ The price of beef has a direct effect on the expenditure of foodstuffs for the people of Jambi Province.

$\mathrm{H} 3=$ Food inflation has a direct effect on protein consumption in Jambi Province.

$\mathrm{H} 4=$ The price of beef has a direct effect on the protein consumption of the people of Jambi Province.

H5= Food expenditure has a direct effect on protein consumption of the people of Jambi Province.

H6= Food inflation has an indirect effect on public protein in Jambi Province through the expenditure of foodstuffs for the people of Jambi Province.

$\mathrm{H} 7=$ The price of beef has an indirect effect on the protein of the people of Jambi Province through the expenditure of foodstuffs for the people of Jambi Province.

\section{METHOD (FOR RESEARCH ARTICLE)}

The research approach used is quantitative research with the scope of the socio-economic conditions of the people of Jambi Province for the period 2007 to 2018, while the research data is in the form of time series data obtained from publications, reports, and from electronic media such as the internet.

Data analysis techniques to answer research problems use descriptive analysis in the form of diagrams, charts and graphs, while to analyze the direct and indirect effects, path analysis is used. Abdurahman (2007) explains that the path analysis model is used if in theory the researcher believes that the analysis has a causal effect pattern. The structure of the causality relationship in the path diagram (Path Diagram) of several variables studied where the independent variable is 
foodstuff inflation (X1) and beef prices (X2), the variable per capita public expenditure is the Intervening variable $(\mathrm{Z})$ and the community protein consumption is the dependent variable Y).

The path diagram between variables is depicted in Figure 1 ..

[Figure 1 about here.]

The path coefficient of the structural equation in this study where:

The first Sub Structural Path Equation $Z=\rho z X_{1}+\rho z X_{2}$ $+\varepsilon_{l}$

Second Sub Structural Path Equation $Y=\rho y X_{1}+\rho y X_{2}$ $+\rho y Z+\varepsilon_{2}$

The direct effect of $\mathrm{X} 1$ and $\mathrm{X} 2$ on $\mathrm{Z}$, and the results of $\mathrm{Z}$ on $\mathrm{Y}$,

$\mathrm{X}_{1}, \mathrm{X}_{2} \rightarrow \mathrm{Z}: \rho z X_{1}, \rho z X_{2} \quad$ 4) $\mathrm{X}_{1}, \mathrm{X}_{2}, \mathrm{Z} \rightarrow \mathrm{Y}: \rho y X_{1}, \rho y X_{2}, \rho y Z_{1}$ $\mathrm{X}_{1}, \mathrm{Z} \rightarrow \mathrm{Z}: \rho y X_{1}, \rho y Z_{1}$ 5) $\mathrm{Z} \rightarrow \mathrm{Y}: \rho y Z, \varepsilon 1$

$\mathrm{X}_{2}, \mathrm{Z} \rightarrow \mathrm{Z}: \rho y X_{2}, \rho y Z_{1}$ 6) $\mathrm{Y} \rightarrow \varepsilon 2$

The indirect effect of $X$ on $Z$ through $Y$,

$X \rightarrow Z \rightarrow Y:$ ( $\mathrm{Xzx}),(\rho y z)$

The equation above shows that the direct results are obtained from the results of the beta value path analysis, while the indirect results are obtained by multiplying the rho coefficient that passes through the intermediate variable with the direct variable.

\section{Hypothesis test}

Hypothesis testing is needed to test the significant level of the effect of the independent variable on the dependent variable. Hypothesis testing is done by comparing the $\mathrm{t}-\mathrm{Sig}$ value with $\alpha$. The hypothesis is described as follows:

H0: $\rho y x 1 \rho y x 2 \rho y z=0$, there is no effect $X$ and $Z$ simultaneously on $\mathrm{Y}$

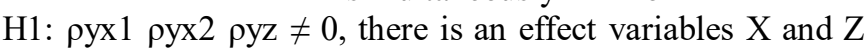
simultaneously on $\mathrm{Y}$

\section{Operational Variables}

The variables in this study are fully illustrated in table 1 as follows.Pengujian Hipotesis

[Table 1 about here.]
The results of a quantitative descriptive analysis using a trend explain where in the period 2007 to 2018 the condition of food product inflation (HDI); public expenditure for foodstuffs (PBM); public protein consumption (KPM); and the price of Beef (HDS) is very volatile. The results of processed data from the publication of the Central Statistics Agency (BPS) Jambi Province in 2020 are statistically shown in Table 1 as follows:

Table 1 shows the condition of Jambi Province from 2007 to 2018 , where IBM on average was 0.53 percent, the PBM Index was 53.63 percent, HDS was Rp.105,428 and KPM was 20,962, with a trend pattern of IBM's conditions towards KPM and HBS. to KPM as in Graphs 1 and 2 as follows:

[Graph 1 about here.]

[Graph 2 about here.]

Source: Processed Data Results 2020

In tables 1 and 2 above, it is illustrated that the foodstuff inflation in Jambi Province in the 2007-2018 period fluctuated, while the people's protein consumption in that period tended to continue to increase, especially in the 2012 to 2018 period. 2007-2018 period, also continued to increase and the highest price occurred in 2016 and then returned to stability.

The pattern of food expenditure for the people of Jambi Province from 2007 to 2018 based on the results of the trent analysis seemed to fluctuate but decreased, while the protein consumption of the people of Jambi Province in the same period tended to increase. The complete pattern of food expenditure for the people of Jambi Province for the period 2007 to 2018 is in full as in Graph 3 below:

[Graph 3 about here.]

\section{Path Analysis Results}

To get the amount of contribution (contribution) of the path coefficient on each path diagram of the causal relationship between variables $\mathrm{X} 1$ and $\mathrm{X} 2$ through $\mathrm{Z}$ to $\mathrm{Y}$, statistical regression analysis is used with the help of the SPSS version 23 application. :

\section{RESULTS AND DISCUSSION}

[Table 2 about here.]

\section{RESULTS}

Descriptive Analysis Results 
[Table 3 about here.]

Furthermore, the results of the path analysis of the direct and indirect effects between the independent variables and the dependent variable and the use of intervening variables are specifically illustrated in Figure 2 below.

[Figure 2 about here.]

\section{Direct influence (Di)}

Table 2 shows the direct effect of IBM on PBM and HDS on PBM with a significance value of 0.861 and 0.057, respectively, these results are greater than 0.05 so that it is stated that there is no direct influence between IBM on PBM and HDS on PBM. Furthermore, in Table 3, it can be seen that the influence of IBM on KPM and HDS on KPM with a significance value of 0.476 and 0.393 respectively, these results are also greater than 0.05 so that it is stated that there is no direct influence between IBM on PBM and HDS on PBM. The results of the analysis of the effect of PBM on KPM were obtained with a significance value of $0.278>0.05$, also explaining that there was no direct influence between PBM on KPM.

\section{Indirect Influence (Intervening)(Ii)}

The results of statistical analysis show that the direct effect between IBM on KPM is -0.247 while the indirect effect of IBM through PPM on KPM is $(0.047 \times-0.367)=-$ 0.017 . Then the total effect of IBM on KPM is the direct effect and the indirect effect obtained is $(-0.247)+(-0.017)=$ -0.264 , where the value of the indirect effect is -0.264 is greater than the value of the direct effect, so it is stated that indirectly IBM through PPM has a significant effect on KPM and vice versa.

The direct effect between HDS on KPM is 0.294 while the indirect effect of HDS through PPM on KPM is (-0.606 $x$ $-0.367)=0.222$. Then the total effect of HDS on KPM is the direct effect and the indirect effect obtained is $0.222+0.294$ $=0.516$, where the value of the indirect effect is 0.516 greater than the value of the direct effect, so it is stated that indirectly HDS through PPM has a significant effect on KPM and vice versa.

\section{Research Hypothesis}

From the results of statistical analysis using path analysis, it is obtained the value of direct and indirect effects so that the research hypothesis can be formulated as in Table 2 below.

[Table 4 about here.]

\section{DISCUSSION}

Protein is needed by the body for the formation and repair of all tissues in the body, including blood, enzymes, hormones, skin, hair, and nails. Protein is also useful for protecting the body so that the balance of acids and bases in the blood and tissues can be maintained and regulate the water balance in the body. Lack of protein can cause impaired cognitive function of the brain so that all other organs of the body will also be disturbed. The fulfillment of individual community protein is very important for the government to pay attention to because its fulfillment is generally influenced by the level of knowledge, social factors, cultural factors, community income levels and is also influenced by the micro and macro conditions of the national economy (Ermon 2012).

The results of statistical analysis in this study show that there is no effect of foodstuff inflation, beef prices and public food expenditure on protein consumption in Jambi Province partially, these results explain that in general, inflation in Jambi Province during the study period which tends to fluctuate does not cause an increase. the price of goods in the market so as not to encourage an increase in public expenditure and public protein consumption.

Ermon (2012) explains that the condition of foodstuff inflation can have a positive or negative impact on food expenditure and public protein consumption, a mild inflation rate will encourage an increase in people's income, and high and uncontrolled inflation (hyperinflation) the economy will experience a sluggishness and an aggregate effect on expenditure of foodstuffs and consumption of public protein directly.

The level of beef prices in Jambi Province also has not affected the condition of public protein consumption and public food expenditure in Jambi Province, this condition shows an increase in beef prices during the research period which continues to increase every year, illustrating that the pattern of protein consumption of the people of Jambi Province, especially animal protein which is sourced from beef only to meet the minimum needs of the community in general. Hanum (2017) argues that Keynes in his previous theory explained that the minimum consumption limit for society does not depend on the level of income, meaning that the level of consumption must be met even though the level of income does not change and this is called autonomous consumption.

There is an indirect effect between foodstuff inflation and the level of beef prices on public protein consumption through public food expenditure during the study period, explaining that when inflation and beef prices do not increase, public expenditure increases because the per capita income also increases encouraging people to consume more and affect protein consumption in general. Dewi (2015) suggests that in a theoretical study, Keynes has suggested that the role of people's income can be the main indicator in the consumption function, meaning that the level of consumption is very much determined by the level of income and other factors that are closely related to public consumption. 
The results of this study, which specifically focuses on analyzing macroeconomic variables that affect people's protein consumption, are different from previous studies, such as the research of Wahyuni (2016), which specifically analyzes the price elasticity of food sources of protein and the area of residence on the share of expenditure on consumption of protein sources and foodstuffs. Umaroha (2018) specifically analyzes the consumption of animal protein as indicated by the consumption of meat, chicken, fish, and milk commodities in Indonesian households. However, in general, the two studies also see the need for government intervention, especially controlling the demand and supply of beef commodities through market operations so that they have a positive effect and can stabilize the price of beef in the market.

Considering the importance of maintaining the people's need for protein, so that people can carry out normal activities and carry out their work properly, the government needs to develop work programs and strategies to control beef prices on the market so that they do not continue to increase. These government programs can be in the form of supporting infrastructure improvement programs, programs to increase farmers' ability to utilize advanced technology and policies to make it easier for farmers / breeders to access capital. The government's strategy will also encourage the realization of food sovereignty towards the economic independence of the community as well as realizing quality human resources.

\section{CONCLUSION}

From the research results, several conclusions can be drawn:

Foodstuff inflation is a macroeconomic variable that has a direct impact on the expenditure of foodstuffs and protein consumption of the people of Jambi Province, because the high and low inflation of foodstuffs will affect the supply and demand of beef in the market as well as have an impact on food expenditure and protein consumption of the people of Jambi Province.

The results also illustrate where the protein consumption of the people of Jambi Province from 2007 to 2018 is in a stable condition and is not affected by the increasing price of beef and foodstuff inflation. This condition occurred because during that period the per capita income of the community continued to increase, so that expenditure on community foodstuffs could also be adjusted to the increase in the price of beef in the market.

\section{ACKNOWLEDGEMENT}

My gratitude goes to the leadership and the lecturers of Muhammadiyah Jambi University for the completion of this

article. It is important to follow up this research as one of the objectives of the activity, namely to encourage the Jambi provincial government to develop appropriate macro and micro economic strategies and policies that can stabilize the supply and demand of beef in the market, as well as improve the quality of community resources through fulfilling community consumption. The role of academics is also important, especially in further research, especially regarding higher quality and higher quality consumption patterns of society as an effort to promote the welfare of the people of Jambi Province 


\section{REFERENCES}

Abdurahman Maman and Muhidin Sambas Ali, 2007, Correlation Analysis, Regression and Pathways in research with the SPSS application program, Publisher: Pustaka Setia, Bandung.

Aísa, R., Pueyom F ,. \& Sanso, M. (2012) Life Expectancy and Labor Supply of The Elderly, Journal of Population Economicsm Vol. 25 (2),

Amir, Amri. 2010. The Effect of Inflation and Economic Growth on Unemployment in Indonesia

Central Bureau of Statistics (BPS), https://jambi.bps.go.id/subject/ accessed from http://www.bps.go.id/, accessed on 5 June 2020.

Bintang, M. (2010). Biochemical research techniques. Jakarta: Erlangga Publisher.

Ermon Muh. Nur, 2012, his research entitled Indonesian consumption and inflation, Faculty of Economics and Business, Banda Aceh 23111 - Indonesia

Gusti ayu Manuati Dewi (2015) The Influence of Income on Consumption in Indonesia: The Development of Theoretical Model and Selection of Empirical Models in Management Department, Faculty of Economics and Business, Udayana University DOI: https://doi.org/10.24843/JEKT.2015.v08.i01.p03

Irma Yusnita Hasibuan, et al (2014) The Impact of Increased Beef Prices on Beef Consumption in Medanjournal Article Journal Of Agriculture And Agribusiness Socioeconomics • June 2014 Indonesia

Khairil, and ikhsan, (2018) Analysis of the influence of UMP, inflation and unemployment on poverty in Aceh province Faculty of Economics and Business, Banda Aceh - Indonesia

Mankiw, N. G. (2013.). Introduction to Macro Economics ,. Jakarta: Publisher Salemba Empat.

Muh. Amir Arham (2018) Supporting Factors of Labor Productivity and Challenges in Indonesia Faculty of Economics UNG File: / C:/Users/Start/Downloads Factors-Driving-Productivity-Labor-Labor-And-Challenges-In -Indonesia\% 20 (1) .Pdf

Niki Ermija et al (2017) entitled Analysis of the causality between inflation and consumption in Indonesia. Faculty of Economics and Business, Banda Aceh 23111 - Indonesia

Nurlaila Hanum, (2017) Analysis of the Influence of Income on Consumption Behavior of Students at Samudra University in Langsa City. Faculty of Economics, Universitas Samudra Langsa Aceh Samudra Ekonomika Journal, Vol. 1, No. October 2, 2017.

Sadono Sukirno, (2017) Introductory Macroeconomics Theory Third Edition 3 publisher rajawali pers.

Soediyono Reksoprayitno (2000) Introduction to Macroeconomics Edition 6 Publisher: BPFE.

Syaipan Djambak, (2011) Linkage Between Aggregate Demand Linkage Between Aggregate Demand and Inflation. Faculty of Economics, Sriwijaya University, South Sumatra, Indonesia ISSN 1829-5843

Winarni, R. (2000) Occupational Nutrition in Hyperkes Counseling and Occupational Health for Paramedics in Pasuruan. East Java Hiperkes and Occupational Health Center

Yuli Angriani 2013 Analysis of the Effect of National Income, Inflation, and Interest Rates on Household Consumption in Indonesia Vol 1, No 02 (2013) Journal of Economic and Development Studies. http://ejournal.unp.ac.id/students/index.php/epb/article/view/128

Conflict of Interest Statement: The authors declare that the research was conducted in the absence of any commercial or financial relationships that could be construed as a potential conflict of interest.

Copyright $($ ) tahun terbit nama belakang and nama belakang. This is an openaccess article distributed under the terms of the Creative Commons Attribution License (CC BY). The use, distribution or reproduction in other forums is permitted, provided the original author(s) and the copyright owner(s) are credited and that the original publi-cation in this journal is cited, in accordance with accepted academic practice. No use, distribution or reproduction is permitted which does not comply with these terms. 


\section{LIST OF GRAPH}

1 Jambi Province Community Food Material Expenditure 2007-2018 …..........................................................

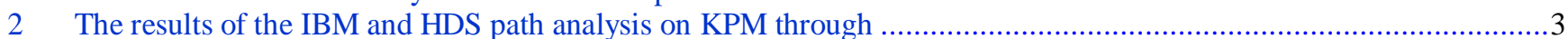

3 Jambi Province Community Food Material Expenditure 2007-2018 ............................................................... 


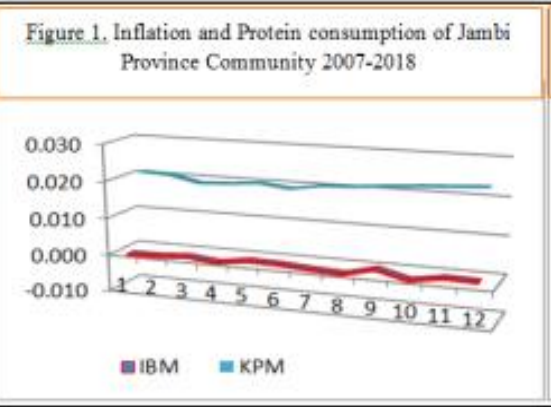

Source: Processed Data Results 2020 


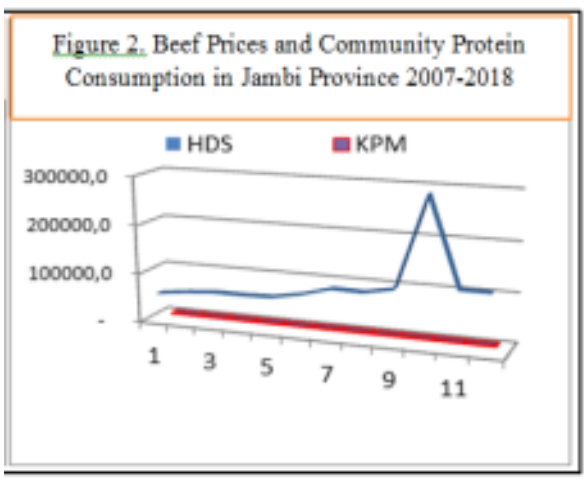

Source: Processed Data Results 2020 


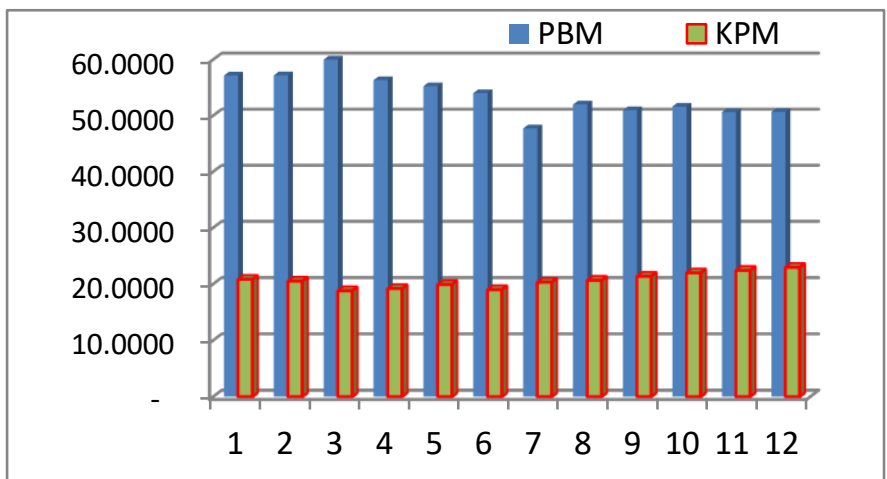

Source: Processed Data Results 2020 


\section{LIST OF FIGURES}

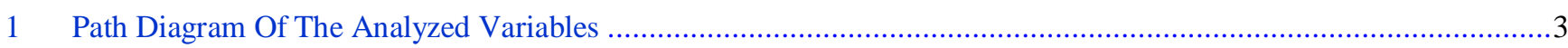

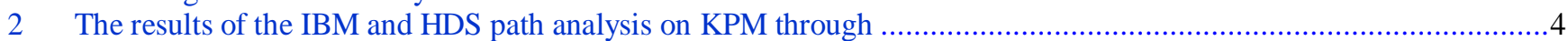




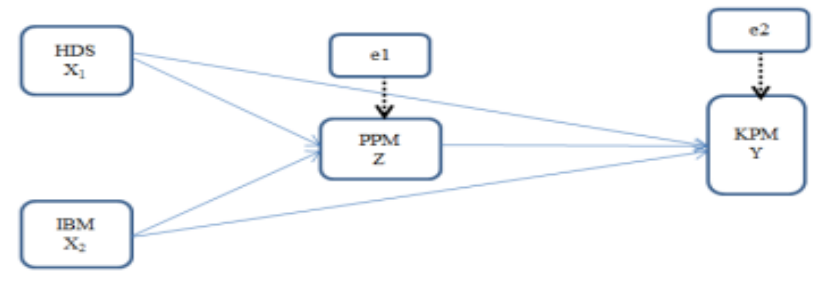

Figure $1 \mid$ Path Diagram Of The Analyzed Variables 


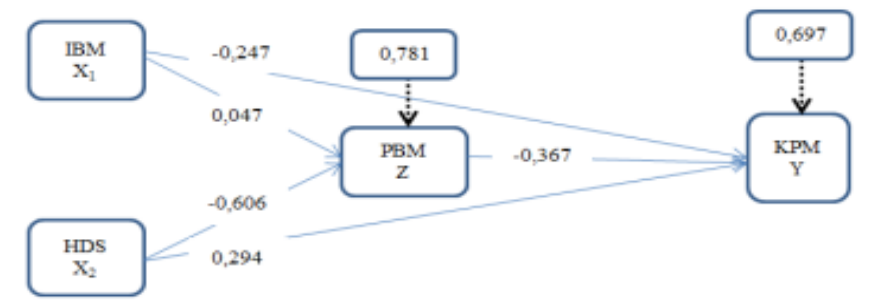

Figure $2 \mid$ The results of the IBM and HDS path analysis on KPM through 


\section{LIST OF TABLES}

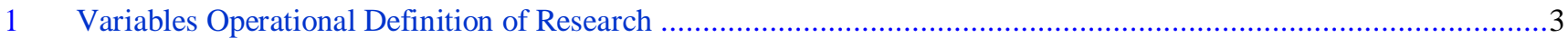

2 Output regression model 1 Influence of IBM and HDS on PBM Jambi Province Hasil Analisi Jalur .......................4

3 Output regression model 2 Effect of IBM and HDS on KPM through PBM in Jambi Province..............................4

4 Research Hypothesis on the influence of IBM, HDS and PBM on KPM in Jambi Province.................................. 
TABLE 1 / Variables Operational Definition of Research

\begin{tabular}{|c|c|c|}
\hline Variabel & Indicator & Symbol \\
\hline \multicolumn{3}{|c|}{ Variabel Independent } \\
\hline $\begin{array}{l}\text { Foodstuff } \\
\text { Inflation } \\
\left(\mathrm{X}_{1}\right)\end{array}$ & $\begin{array}{l}\text { producer price index that follows } \\
\text { changes in prices paid by } \\
\text { consumers for foodstuff products } \\
\text { (percentage). }\end{array}$ & (IBM) \\
\hline $\begin{array}{l}\text { Beef Price } \\
\left(\mathrm{X}_{2}\right)\end{array}$ & $\begin{array}{l}\text { wholesale price of Beef Jambi } \\
\text { Province }(\mathrm{Rp} / \mathrm{Kg}) \text {. }\end{array}$ & (HDS) \\
\hline \multicolumn{3}{|c|}{ Variabel Intervening } \\
\hline $\begin{array}{l}\text { Food } \\
\text { Expenditures } \\
\text { (Z) }\end{array}$ & $\begin{array}{l}\text { expenditure per capita of the } \\
\text { community in the food goods } \\
\text { group of Jambi Province in units } \\
\text { (percentage). }\end{array}$ & $(\mathrm{PBM})$ \\
\hline \multicolumn{3}{|c|}{ Variabel Dependent } \\
\hline $\begin{array}{l}\text { Public Protein } \\
\text { Consumption } \\
\text { (Y) }\end{array}$ & $\begin{array}{l}\text { consumption of protein in the } \\
\text { form of meeting people's needs, } \\
\text { for nutrition from protein } \\
\text { consumption in units ( } \mathrm{Kg} / \text { year). }\end{array}$ & (KPM) \\
\hline
\end{tabular}


TABLE 2 / Output regression model 1 Influence of IBM and HDS on PBM Jambi Province Hasil Analisi Jalur

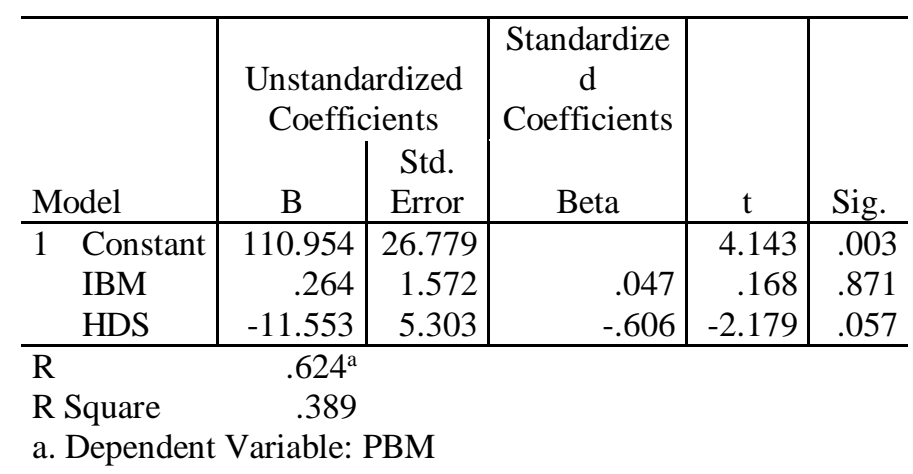


TABLE 3 / Output regression model 2 Effect of IBM and HDS on KPM through PBM in Jambi Province

\begin{tabular}{|c|c|c|c|c|c|}
\hline \multirow[b]{2}{*}{ Model } & \multicolumn{2}{|c|}{$\begin{array}{l}\text { Unstandardized } \\
\text { Coefficients }\end{array}$} & \multirow{2}{*}{$\begin{array}{c}\text { Standardize } \\
\mathrm{d} \\
\text { Coefficients } \\
\text { Beta }\end{array}$} & \multirow[b]{2}{*}{$\mathrm{t}$} & \multirow[b]{2}{*}{ Sig. } \\
\hline & B & $\begin{array}{l}\text { Std. } \\
\text { Error }\end{array}$ & & & \\
\hline 1 Constant & 1.258 & .337 & & 3.727 & .006 \\
\hline IBM & -.011 & .012 & -.247 & -.937 & .376 \\
\hline HDS & .044 & .048 & .294 & .904 & .393 \\
\hline PBM & -.003 & .002 & -.367 & -1.165 & .278 \\
\hline $\begin{array}{l}\mathrm{R} \\
\mathrm{R} \text { Square }\end{array}$ & $\begin{array}{l}.717^{\mathrm{a}} \\
.514\end{array}$ & & & & \\
\hline
\end{tabular}


TABLE 4 / Research Hypothesis on the influence of IBM, HDS and PBM on KPM in Jambi Province

\begin{tabular}{|c|c|c|}
\hline \multicolumn{3}{|c|}{ Hipotesis Langsung } \\
\hline $0.861>0,05$ & $\begin{array}{l}\mathrm{H} 0 \text { is } \\
\text { rejected } \\
\mathrm{H} 1 \\
\text { accepted }\end{array}$ & $\begin{array}{l}\text { This means that there is no } \\
\text { direct influence of IBM on } \\
\text { PBM in Jambi Province. }\end{array}$ \\
\hline $0.057>0,05$ & $\begin{array}{l}\mathrm{H}_{0} \text { is } \\
\text { rejected } \\
\mathrm{H}_{2} \text { accepted }\end{array}$ & $\begin{array}{l}\text { This means that there is no } \\
\text { direct influence of HDS on } \\
\text { PBM in Jambi Province. }\end{array}$ \\
\hline $0,476>0,05$ & $\begin{array}{l}\mathrm{H}_{0} \text { is } \\
\text { rejected } \\
\mathrm{H}_{3} \text { accepted }\end{array}$ & $\begin{array}{l}\text { This means that there is no } \\
\text { direct influence of IBM on } \\
\text { KPM in Jambi Province. }\end{array}$ \\
\hline $0,393>0,05$ & $\begin{array}{l}\mathrm{H}_{0} \text { is } \\
\text { rejected } \\
\mathrm{H}_{4} \text { accepted }\end{array}$ & $\begin{array}{l}\text { This means that there is no } \\
\text { direct influence of HDS on } \\
\text { KPM in Jambi Province. }\end{array}$ \\
\hline $0,278>0,05$ & $\begin{array}{l}\mathrm{H}_{0} \text { is } \\
\text { rejected } \\
\mathrm{H}_{5} \text { accepted }\end{array}$ & $\begin{array}{l}\text { This means that there is no } \\
\text { direct influence of PBM on } \\
\text { KPM in Jambi Province. }\end{array}$ \\
\hline $\begin{array}{l}I i>D i \\
0,264> \\
-0,247\end{array}$ & $\begin{array}{l}\mathrm{H}_{0} \text { accepted } \\
\mathrm{H}_{1} \text { is } \\
\text { rejected }\end{array}$ & $\begin{array}{l}\text { This means that there is an } \\
\text { indirect effect of IBM on } \\
\text { KPM through community } \\
\text { PBM in Jambi Province. }\end{array}$ \\
\hline $\begin{array}{l}I i>D i \\
0,516> \\
0,294\end{array}$ & $\begin{array}{l}\mathrm{H}_{0} \text { accepted } \\
\mathrm{H}_{1} \text { is } \\
\text { rejected }\end{array}$ & $\begin{array}{l}\text { This means that there is an } \\
\text { indirect effect of HDS on } \\
\text { KPM through community } \\
\text { PBM in Jambi Province. }\end{array}$ \\
\hline
\end{tabular}


